\title{
E-business for Nations: A Study of National Level E- business Adoption Factors Using Country Characteristics-Business-Technology-Government Framework
}

\author{
Venkata Vijay K Durbhakula ${ }^{1}$ and Dan J. Kim² \\ ${ }^{1}$ University of Houston-Clear Lake, Computer Science, durbhakulav9896@uhcl.edu \\ ${ }^{2}$ University of North Texas, Information Technology and Decision Sciences, Dan.Kim@unt.edu \\ Received 30 July 2010; received in revised form 16 January 2011; accepted 16 February 2011
}

\begin{abstract}
Earlier studies on e-business adoption factors have been conducted from a firm level perspective or from a single country level perspective. In this study, we propose a framework entitled country characteristicsbusiness-technology-government model that addresses a theoretical perspective on e-business adoption factors required for a nation level e-business development. The major goal of this study is four-fold: (i) to review existing key literature on e-business across the countries and identify key factors affecting e-business adoption, (ii) to propose a research model based on the identified factors, (iii) to test the proposed model empirically using the national level macro economic data from secondary sources, and (iv) to provide insightful discussions for country administrators, policy makers, and academics. The limitations and future directions of the study are also discussed.
\end{abstract}

Keywords: E-business development, E-business use, E-presence, Country-business-technologygovernment framework, Country-level data 


\section{Introduction}

Global electronic business (e-business hereafter, In line with Beyono-Davues's definition (Beyono-Davies, 2004), we define electronic business as the use of the Internet and communication technologies in support of all business activities) trade volume is growing at a very rapid pace. According to US e-commerce statistics, the Internet trade volume is expected to reach $\$ 248.7$ billion by 2014 . This signifies an increase of 60 percent to the current scenario in 2009. According to the statistics of EuroStats (Site 1) and Office of National Statistics (ONS) (UK) (Site 2), the UK market for e-business was 540 million pounds in 2009. The Asia-Pacific report of Forrester predicts that countries in the region would triple their e-commerce market by 2015 with China being highest with $\$ 159.4$ billion [52]. The remaining countries like Japan, Australia, Korea, and India would make about \$72.1 billion, \$29.9 billion, \$20.7 billion, and $\$ 6.5$ billion respectively by 2015 [52]. As suggested by these reports, e-business growth is high in some countries, but some others are still behind the curve. Under these circumstances, the following would be an interesting and challenging research question: How and why do some countries better than others in country-level ebusiness development with government support? In other words, what are the dimensional factors that affect a country-level e-business development?

E-business is no longer an alternative; it is imperative. E-business has a strong influence on the global economy [24]. The growth of e-business furnishes the overall business environment and productivity-enhancing practices for a country [2], [30]. E-business is being adopted by countries of different sizes, cultures, and economies. Despite variations in these factors among countries, there should be a unique framework and that is what many countries are looking forward to implementing.

There has been much research [22], [36], [55], [57] on e-business development and factors contributing to its development. Most research on e-business concentrates on either organizational or individual level of analysis for various Business-to-Business (B2B) or Business-to-Commerce (B2C) activities. There is no unique framework that a nation or country administrator can abide by for developing e-business in the nation. Thus, in this study, we attempt to fill this gap by answering the questions above.

The goal of this study is four-fold: i) to review existing key literature on e-business across the countries and identify key factors affecting e-business adoption, ii) to propose a research model based on the identified factors, iii) to empirically test the proposed model using national level data, and finally iv) to provide some theoretical and practical implications to country administrators, academics, and policy makers.

The rest of the paper is organized as follows. The next section presents literature review on e-business framework from a country level perspective. Section three proposes a framework based on the identified factors from previous literature. Then, we explicate the contexts necessary for e-business development to formulate a research model and hypotheses. Next, using data from 61 countries (see Table 1), we test the hypotheses formulated in the research model. Finally, we conclude the paper with a set of discussions including contributions, limitations, and future directions of the study.

\section{Literature Review}

Although many studies [55], [58] analyze the e-business adoption factors in a business organization level context, relatively few studies [5], [21]-[22], [24], [40], [42] examine e-business from a country-level perspective. Gibbs et al. [21] presents a global perspective of e-business, discussing environmental and policy factors affecting country's ebusiness adoption decisions. Their empirical analysis used data from only 10 countries and their main focus was only on environmental and policy factors for e-business adoption. Some other studies [25], [56], [58]-[59] also discuss cross-country e-business adoption factors, but are constrained to cross-country firm level studies. In another cross-country level study, Simon [40] states several technical and societal critical success factors that a developing country should adhere to for successful electronic services. Another cross-country study by Berthon et al. [5] gives a different variant from others - their main crux was the importance of cultural values and corruption in building crosscountry e-relationships.

E-business development and other facilitators contributing to it have been studied profoundly in the previous literature. Much of the earlier literature typically adopted the Technological-Organizational-Environmental (TOE) framework to study about e-business [42], [43], [56], [58]-[59]. TOE framework identifies three factors of a firm that could influence adoption and implementation of technological innovations: Technological context, Organizational context, and Environmental context. Technology context refers to the internal and external technologies available to the firm. Organizational context refers to the organizational characteristics and resources, such as the quality of its human resources, amount of slack resources, etc. Environmental context refers to the environmental characteristics in which the firm conducts its business. These three contextual factors influence the firm decision to adopt an innovation, leading to increase in firm performance. The study conducted by [42] is the foremost work on the ebusiness development from a global perspective. Their model is also based on the TOE framework and their main focus is on the integration of e-business development and e-government development for enhancing the business 
competitiveness of a nation. While their study united both e-business development and e-government development from a global perspective, they focus on the aspect of a country. Another study by Gregorio et al. [22] also sheds light on global e-business development and the factors necessary for a successful e-business activity. They list Logistics, Path Dependence, Entrepreneurial Activity, and Regional Differences as some of the novel factors contributing to e-business development along with some other well-defined factors. Although their model could be applied to e-business development, their main focus is only on the e-business activity, which by itself cannot make a reasonable argument for a framework at the global level. Purcell and Toland [38] give a brief summary of the South Pacific region's e-business development and opportunities that can be adopted for their region. Spremic and Hlupic [41] focus on the implementation of e-business from the Croatian perspective and suggests some practices and implications. Some other studies [1], [8]-[9], [14], [27], [33], [41] focus on e-business development in a country from a certain perspective or a sector. For example, [1] explains about the adoption of e-business in the case of a NonGovernmental Organization (NGO) in Jordan. He uses they TOE framework to study e-business diffusion for Jordan's NGO. Another similar study by [54] also discusses some factors about e-business diffusion in Singapore. Although the above studies focus on e-business from a country-level perspective their models are restricted to a single country.

The above literature review suggests that there are very few studies on global-level e-business from a multi-national level. To our best knowledge, there are very few cross-country level empirical studies to explain the e-business development from a holistic multi-dimensional perspective. This research aims to fill this gap by focusing on nationallevel e-business development from multi-dimensional perspective.

\section{Research Framework and Hypothesis}

The TOE framework provides three contexts for adoption and implementation of technological innovations: technological context, organizational context, and environmental context. Some of the earlier studies extended the TOE framework to study technological innovations at a national level. Although the TOE framework has been examined by studies on various IS domains, many of these studies use this framework in firm-level context. Therefore, the contexts of TOE are not sufficient to study a multi-national level study. Also, the TOE framework is based on technology adoption. E-business depends heavily upon the technology, but it may not be the only factor in e-business adoption. Hence, drawing from the previous research constructs [28], [44] and theoretical models such as Technological-Organizational-Environmental (TOE), we identified four dimensions for a successful global e-business development: Country characteristics, Business, Technology, and Government dimension. The Technology dimension has been adapted directly from the TOE framework. Since the organizational factor of the TOE cannot be applied directly to a country level study, we map it to the country characteristics dimension. Government dimension has been identified as another important dimensional factor in any multi-national level study. Synthesizing these four dimensions, we propose a framework (Figure 1) that depicts the necessary constructs required for a successful ebusiness development for a country.

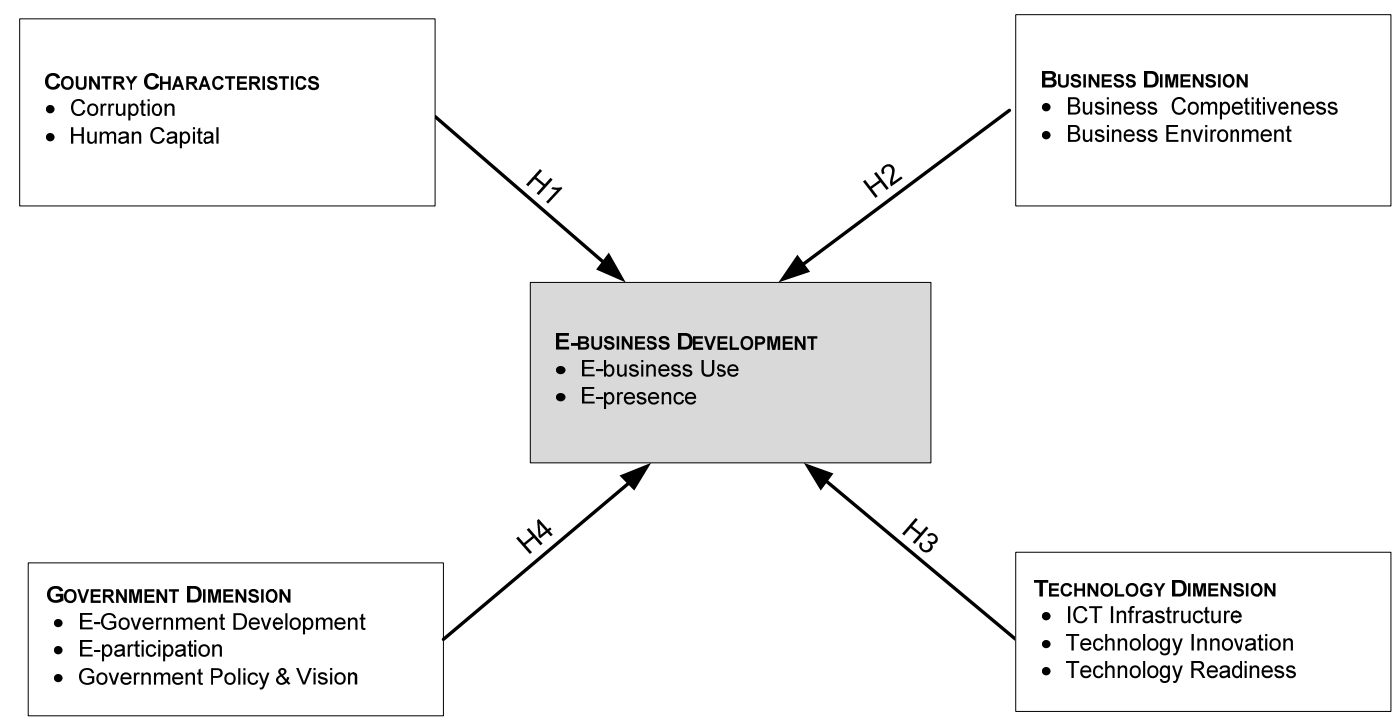

Figure 1: Country-business-technology-government adoption model for nations e-business development

\subsection{E-business Development}

Growth in adoption of e-business by businesses would increase their revenue and profits. Concurrently, an upturn in business processes would increase the overall economy of a nation [21]. This kind of economic growth could sustain 
the nation to an extent in this global competitive world. E-business Development is defined as the degree of maturity with which a nation's business conducts its transactions using the Internet [22]. In this study, we assess country level e-business development with two indicators: E-business use and E-presence.

E-business use can be defined as the extent to which e-business is being used by the businesses in a nation. In this study, it is measured as the internet use by businesses in the particular country to buy and/or sell products and services. This use of e-business is increasing constantly among the firms for their front-end and back-end business processes. Although e-business use is varied among the firms depending on their type and size, all of them use ebusiness in their daily business operations, ranging from product design to pre- and post-sales services [31]. According to Kalakota and Whinston [26], cost benefits are the main reason for increased use of e-business by firms. These benefits can be in the form of reduced transaction cost, improved logistics, lower personal costs, and reduced support costs. The level of business use of Internet indicated the level of development of e-business in the country. This means that a country with a high volume of business (B2B and B2C) over the Internet has a high level of ebusiness in it. Although we do not completely agree that only the Internet use by business increases e-business in a nation, we argue that e-business measured as the Internet use by business would yield an approximate estimation of e-business development in a country. There are relatively few data sources that collect the statistics of indicators like e-business use across the countries.

Another indicator of e-business development is E-presence, which is defined as the measure of the number of cyber store-fronts for $\mathrm{B} 2 \mathrm{~B}$ and $\mathrm{B} 2 \mathrm{C}$ activities taking place within a country. It indicates the existence and transaction volume occurring over the websites of the country. In this study, e-presence is the list of the number of e-commerce and e-business websites and activities by them on the web. To successfully measure a countries e-business development, it is essential to know about its existence along with its use. The dependent indicator, e-business use, indicates the use of e-business by firms of a nation resulting in transactions from the firm. These transactions are the activities that are carried out either internally or externally by the firm. The activities that are internal to the firm are the e-business activities and the activities that are external to the firm are the e-commerce activities. With this dependent indicator, E-presence aims to aggregate both of them by trying to explain the level of online activities in various nations. It is believed that E-presence in a country is driven by e-readiness factors, and that differences in online activities in different countries are attributable to adoption of e-business [22]. We can posit that e-business adoption within a country is dependent on the level of E-presence taking place within a country, and this variable can support our definition of a nation's use of the Internet for supporting e-business.

\subsection{Country Characteristics}

Some country-level characteristic factors could foster e-business development within a country. Past studies have identified demography, population, and economic resources as some of the factors that contribute to e-business development [38], [54]. Berthon et al. [5] suggest that the level of the corruption in a country affects the e-business development of the country. Another country characteristic that is to be considered is human capital. Among the national resources that a country possesses, citizens' knowledge appears to be a vital resource for e-business development [6], [19]. Educated citizens can use and implement e-business as like organizations and nations do. The usage and implementation of e-business by citizens can be in both B2B and B2C channels of business transactions. This kind of utilization of e-business leads to increased business performance thereby increasing ebusiness of a nation as a whole. Hence from above discussion we can posit that:

H1: The E-business development in a country is associated with the country characteristics (i.e. corruption and human capital).

\subsection{Business Dimension}

This dimension indicates the external factors needed for a country to adopt e-business. Businesses need to adopt ebusiness as they deploy their applications more on a international basis [15]. Earlier research [32] shows that ebusiness has an effect on the performance of the firms. Businesses can interact with each other through e-business and therefore increase benefits to their buyers and suppliers. An increase in use of e-business by individual firms' processes could lead to an increase in the overall productivity of the nation as a whole [16]. In this way, the ebusiness development in a country expands along with an increase in the economic growth of the nation.

Business dimension has two indicators: business environment and business competitiveness. Business environment pertains to the general business climate within a country. It is mainly concerned with the operations that affect firms in a nation such as government activities, social and economic factors, and technological developments. A better business environment can lead to an increase in e-business development of a country. Business competitiveness of a nation is another indicator of our business dimension. The business competitiveness of a nation is an indicator of the micro-economic capabilities of its constituents via productivity and living standards [37]. Previous research has shown that e-business enhances the performance of large firms by enabling them to transact with each other efficiently and effectively [12]. This increase in performance of firms leads the national performance of the business firms in aggregated way. This increases the productivity of a nation as a whole, leading to an increase in business 
competitiveness [16]. Hence we can state that business competitiveness and e-business development has a positive relationship in a nation. From the above discussion we can postulate that:

H2: The E-business development in a country is associated with the business dimension (i.e. business competitiveness and business environment).

\subsection{Technology Dimension}

Information technology related constructs such as technology infrastructure, country-level technology innovation, and technology readiness have been demonstrated as important factors for e-business development by many past studies [10], [43], [59]. Combining variables related to technology, we propose technology dimension as one of the constructs that affect the national level e-business development. The dimension has three variables: Information and Communications Technology (ICT) infrastructure, Technological innovation, and Technological readiness. ICT Infrastructure refers to technologies that enable internet-related businesses. ICT Infrastructure has influence on the volume of a nation's Internet Transactions or on the number of e-business websites in a country [22]. A better ICT Infrastructure enhances e-business development [17]. Technological Innovation refers to nations' needs to innovate new technologies to increase their productivity. Different nations need to adopt different technological innovations to be competitive in a global economy [37]. Phan [36] posits that e-business is always driven by competitive advantages by world nations.

Technological Readiness "consists of technology infrastructure and Information Technology (IT) human resources, and technology infrastructure refers to technologies that enable Internet-enabled businesses and IT human resources refer to IT professionals possessing the knowledge and skills to implement Internet-related applications" [57] p. 27. From this definition, it is reasonable to say that technological readiness is affected not only by physical assets, but also by human resources. Technology infrastructure builds a platform for the e-business; IT human resource provides knowledge required for e-business applications. Therefore, countries with greater technological readiness are in a better position to adopt e-business. We expect that technological readiness has a strong effect on the e-business development of a country. Apart from the above indicators, many other technological factors like technology availability and technology usage can contribute to e-business development in their countries [42]. From the above discussion we postulate a hypothesis about technology.

H3: The E-business development in a country is associated with the technology dimension (i.e. ICT Infrastructure, technological innovation, and technological readiness).

\subsection{Government Dimension}

The Government dimension is identified as a key factor in many studies [34] for a company level e-business adoption decision. Every government should not only make use of the Internet by itself but also actively encourage business and consumers to use the Internet [40]. A government could support industries or research environments by providing subsidies, by procurement, or government itself acting as a trusted third party [34]. Jutla et al. [25] state that a government should support e-business by using partnership models. Some studies [13] have also spoken about International Trade Agreement between governments to foster e-business. For example, the Korean government came up with a $u$-KOREA Master Plan in an effort to boost e-business development in its country. Many other countries like Malaysia, China, Singapore, and Chile are also developing strategies to promote e-business in various ways [40].

Government dimension has three indicators: E-government development, E-participation, and Government policy \& vision. As discussed above many governments are bringing forth various projects for developing e-business in their country. Many of these e-government projects are meant to enhance the relationship between the government and its citizens or firms. According to Cohen [11], government activities in public domain encourages businesses to adopt same kind of activities. Greater usage of ICT by governments is said to have influence citizens and businesses, encouraging them to adopt e-business [43]. Thus, we expect that e-business development in a country depends on e-government development and the extent to which governments involve themselves in ICT enabled activities.

E-participation is another indicator of Government dimension. E-participation is defined as at the level of a country's willingness to engage its citizens in e-government process [49]. E-government development is influenced by the citizens' use of their services. Any e-government project should not only be usable to its citizens but also encourage them to participate in e-government service. This kind of participation enhances e-government development [4], [49]. Increase in e-government development spurs e-business development [43].

Government policy and vision is the last indicator of our government dimension. Economist Intelligence Unit (EIU) [18] identified Government policy and vision as one of the factors for formulating their e-readiness rankings. They define this indicator as the government rules and strategies which are employed for successful e-business development within a country. The government rules and strategies significantly impact and improve the e-business development in a country [35], [41]. Better governments' policies towards ICT development will encourage 
businesses to adopt e-business at a high rate, thereby increasing e-business development of a nation. From the above discussion we postulate that:

H4: The E-business development in a country is associated with the government dimension (i.e. e-government development, e-participation, and government policy \& vision).

\section{Research Method \& Data Collection}

Since the unit of analysis of this study is country-level, it is required to use multi-national level data to test the proposed research model and hypotheses. Due to the fact that there is no single database that has all the values required for this study, we use secondary data from various sources and combine them together to make an appropriate data set to test the research model and hypotheses. Two major data sources that we use in this study are the United Nations Global e-Government Readiness Report [40] and the World Economic Forum (WEF) Global Competitiveness Report [50]. Along with these reports we also use EIU E-readiness ranking report [18] and World Economic Forum Global Information Technology Report [51]. These are the major secondary sources available recently. WEF has been publishing the global competitiveness report from many years; the UN started publishing United Nations e-Government Readiness Report since 2003. These agencies release reports in span of few months, and hence the data is contemporary and comparable. After analyzing common data points across the report used, we have a set of data from 61 countries for analysis (see Table 1 for the list of countries analyzed). All the reports used in this study are considered reliable and have been extensively used in past academic research [42]-[43], [56][57].

Table 1: List of countries analyzed

\begin{tabular}{l}
\hline Total Number of Countries Analyzed =61 \\
\hline Algeria, Argentina, Australia, Austria, Belgium, Brazil, Bulgaria, Canada, Chile, China, Colombia, Czech \\
Republic, Denmark, Ecuador, Egypt, Estonia, Finland, France, Germany, Hungary, India, Indonesia, \\
Ireland, Israel, Italy, Jamaica, Japan, Kazakhstan, Latvia, Lithuania, Malaysia, Malta, Mexico, Netherlands, \\
New Zealand, Nigeria, Norway, Pakistan, Peru, Philippines, Poland, Portugal, Russian Federation, Saudi \\
Arabia, Singapore, Slovak Republic, Slovenia, South Africa, Spain, Sri Lanka, Sweden, Switzerland, \\
Thailand, Trinidad and Tobago, Turkey, Ukraine, United Arab Emirates, United Kingdom, United States, \\
Venezuela, Vietnam
\end{tabular}

This secondary data research offers advantages such as the ability to analyze large scale data from cross-sectional countries, easy reproducibility, etc. Using secondary data limits our capabilities to using only those variables listed in their databases, but it is a well used practice done in many research areas and previous research papers [5], [22], [42]-[43], [56], [58]-[59].

As depicted in the research model (Figure 1), there are 12 constructs for the five dimensions. For the dependent construct of the research model, e-business development, two variables are used: e-business use and e-presence. $E$-business use is the vital variable of the dependent construct of the proposed framework. As discussed earlier, ebusiness use is measured as the extent of business internet use taken from the Global Information Technology Report 2009 [51]. This indicates internet use by businesses in a country to buy/sell products and services. The high level of e-business in a nation indicates the high volume of business conducted through online via the Internet. Hence, in our study we use this as a measure for e-business use. Together, both e-business use and e-presence gauge e-business development in a country. Although these are not the exact measures for e-business development in a country, with the available secondary data on e-business development, we came up with these measures. Although some studies have proposed frameworks for measuring e-business at the global level [10], [47], there are only a few countries that publish their e-business national E-stats [23]. Hence in absence of reliable data, we use this available measure for e-business development.

Along with e-business use as a secondary data from Global Information Technology Report 2009, we develop a measurement of a country-level e-presence using the yahoo directory service. E-presence is measured by number of websites reported in the yahoo directory service within a country that is divided by the population of the country to make its relative scale in terms of the population size of countries. From the yahoo directory listing, B2B and B2C activity were measured through count measure of all the websites listed under the categories of Business to Business and Shopping and Services in each countries section of yahoo directory. Total e-presence is then measured by summing B2C and B2B activity and dividing it by the country's population. The total measure was then transformed using logarithmic function to approximate to normal distribution, to allow regression.

The Country Characteristics dimension has two indicators: Human Capital and Corruption. Human capital is taken from the UN e-Government Readiness Report 2008 as the Human Capital Index. The data for the Human Capital Index is from UNDP education index, which is a composite weight of the adult literacy rate and the combined primary, secondary and tertiary gross enrollment ratio with two-thirds weight given to adult literacy and one-third to gross enrollment ratio [49]. Corruption is measured from the work of Transparency International (Site 3), which has published Corruption Perceptions Index (CPI) from many years. The CPI is essentially a poll of polls derived from 
multiple sources: the general public, resident and non-resident business people, and country experts. Countries are scored on a range of 0 to 10 scale, where the least corrupt countries have the highest scores, and the most corrupt the lowest scores.

The Business Dimension has two indicators: Business Environment and Business Competitiveness. Business Environment is taken from the EIU E-readiness rankings 2009. EIU calculated the business environment with 74 sub indicators to provide a comprehensive view of every country's attractiveness as a trading economy and as a destination for business investment. Business Competitiveness of a nation is an indicator of the micro-economic capabilities of its constituents. Competitiveness is thus related to nation's standard of living and prosperity [37]. It is measured by the global competitiveness index taken from the Global Competitiveness Report 2008.

The Technology Dimension has three variables: ICT infrastructure, Technology innovation, and Technology readiness. ICT Infrastructure is measured by the Telecommunication Infrastructure Index from the UN e-Government Readiness Report 2008. The Telecommunication Infrastructure Index is a composite weighted average index of six primary indices based on basic infrastructural indicators, which define a country's ICT Infrastructure capacity [49]. Technology readiness is taken from Global Competitiveness Report 2008 as the Technological readiness pillar. The Technological readiness measures the agility of an economy to adopt existing technologies and to enhance the productivity of its industries. Technology Innovation is also taken from the Global Competitiveness Report 2008 as the Innovation pillar. The Technological Innovation measures the Innovation capability of the country and the environment that is conducive to innovative activity, supported by both the public and private sectors.

Table 2: Data sources

\begin{tabular}{|c|c|c|}
\hline Variable & Measure & Source \\
\hline $\begin{array}{l}\text { E-business Development } \\
\text { (i) E-business Use } \\
\text { (ii) E-presence }\end{array}$ & $\begin{array}{l}\text { Extent of Business Internet Use } \\
\text { Count of number of B2B and } \\
\text { B2C websites in a country } \\
\text { divided by population of the } \\
\text { country }\end{array}$ & $\begin{array}{l}\text { Global Information Technology Report } 2009 \\
\text { [51] } \\
\text { YAHOO Directory Service } \\
\text { http://dir.yahoo.com }\end{array}$ \\
\hline $\begin{array}{l}\text { Country Characteristics } \\
\text { (i)Corruption } \\
\text { (ii) Human Capital }\end{array}$ & $\begin{array}{l}\text { Corruption Perceptions Index } \\
\text { Human Capital Index }\end{array}$ & $\begin{array}{l}\text { Transparency International Website (Site 3) } \\
\text { UN E-government Report } 2008 \text { [49] }\end{array}$ \\
\hline $\begin{array}{l}\text { Business Dimension } \\
\text { (i)Business } \\
\text { Competitiveness } \\
\text { (ii)Business Environment }\end{array}$ & $\begin{array}{l}\text { Global Competitiveness Index } \\
\text { Business Environment } \\
\text { Category }\end{array}$ & $\begin{array}{l}\text { Global Competitiveness Report } 2008 \text { [50] } \\
\text { Global Information Technology Report } 2009 \\
{[51]}\end{array}$ \\
\hline $\begin{array}{l}\text { Technology Dimension } \\
\text { (i) ICT Infrastructure } \\
\text { (iii) Technology Innovation } \\
\text { (iv) Technology Readiness }\end{array}$ & $\begin{array}{l}\text { Infrastructure Index } \\
\text { Innovation Pillar } \\
\text { Technological Readiness Pillar }\end{array}$ & $\begin{array}{l}\text { UN E-government Readiness Report } 2008 \\
\text { [49] } \\
\text { Global Competitiveness Report } 2008 \text { [50] } \\
\text { Global Competitiveness Report } 2008 \text { [50] }\end{array}$ \\
\hline $\begin{array}{l}\text { Government Dimension } \\
\text { (i) E-government } \\
\text { Development } \\
\text { (ii) E-participation } \\
\text { (iii) Government policy \& } \\
\text { vision }\end{array}$ & $\begin{array}{l}\text { Web Measure Index } \\
\text { E-participation Index } \\
\text { Government policy \& vision } \\
\text { Category }\end{array}$ & $\begin{array}{l}\text { UN E-government Readiness Report } 2008 \\
\text { [49] } \\
\text { UN E-government Readiness Report } 2008 \\
\text { [49] } \\
\text { EIU E-readiness Ranking } 2009 \text { [18] }\end{array}$ \\
\hline
\end{tabular}

The Government Dimension also has three indicators: E-government development, E-participation and Government policy and vision. The construct of e-government development is indicated by the Web Measure Index from the UN e-Government Readiness Report 2008. The Web Measure Index is based upon a five-stage model, ascending in nature, and building upon the previous level of sophistication of a country's online presence. The Web Measure Index is an indicator of the sophistication and development of the e-government websites of that particular country. E-participation is taken from the UN e-Government Readiness Report 2008 as the E-participation Index. Eparticipation is defined as the level of a country's willingness to engage citizens in e-government process. The Government policy and vision indicator is taken from the EIU E-readiness rankings 2009. EIU defines Government policy and vision as one of the category indicators to calculate e-readiness of a country. This indicator analyzes the 
availability of digital channels to individuals and businesses for accessing public services, engaging their citizens to both obtain government information about civic issues and consultation with government officials [42].

As variables are taken from multiple studies, we only consider the country data that are common from all the reports. After analyzing the common data points (countries) we have a set of data from 61 countries. Table 2 summarizes the detailed description of the set of secondary data collection.

\section{Data Analysis and Results}

For the data analysis, we employ Partial Least Squares (PLS) [3], [7], [53] as it allows for constructs to be modeled as either formative or reflective indicators, as is the case of the research model of this study [20]. PLS also imposes minimal demands in terms of sample sizes, measurement scales, and residual distributions to validate a model compared to other techniques like structural equation modeling [20], [53]. Not only this, PLS is a robust technique against other data structural problems such as skew distributions and omissions of regressors. Many studies have found it be an effective method of analysis [42]-[43], [46], [58]. The proposed model hypotheses are tested using PLS. The results are depicted below (See Figure 2)

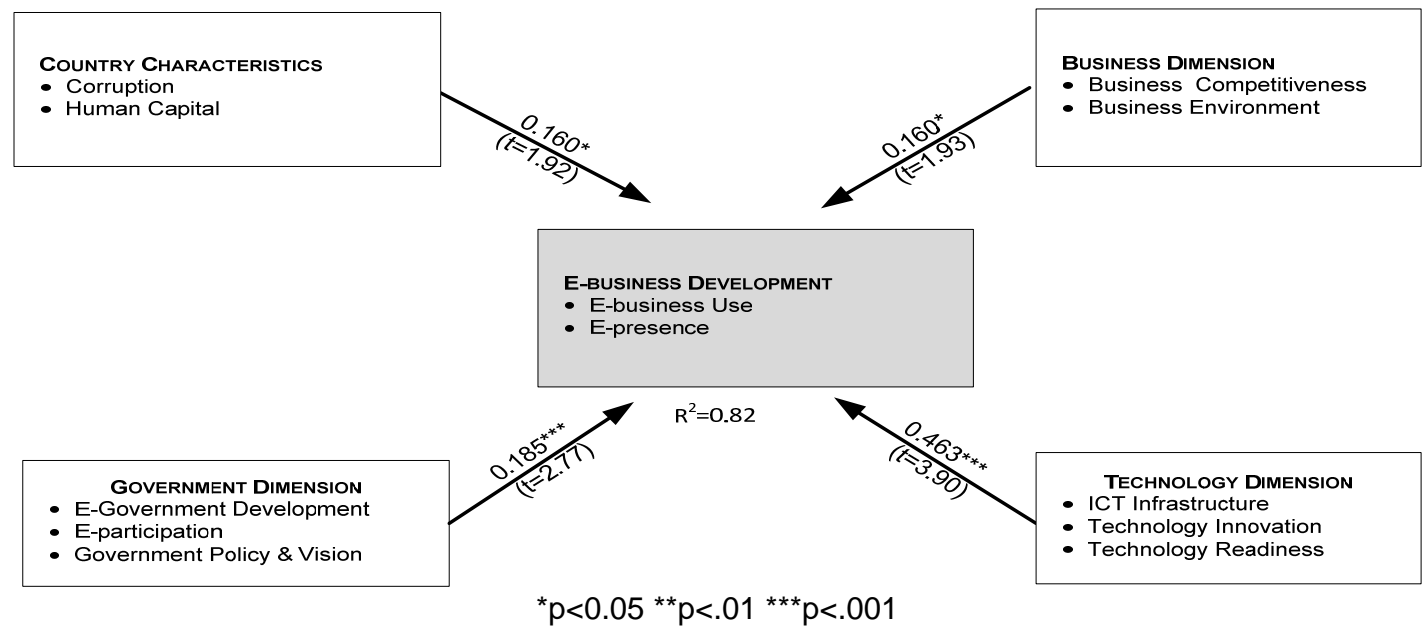

Figure 2: E-business development - Results of PLS analysis

From the results, we see that hypotheses 1, which states that e-business development in a nation has a positive association with the nation's country characteristics, received sufficient support (path=0.160, $t=1.92, p<0.05$ ). Hypothesis 2, which states that business process in a country is positively associated with e-business development, also received sufficient support (path $=0.160, t=1.93, p<0.05$ ). Although these results did not receive a strong support, with the received sufficient support, we could state that both country characteristics and business process in a nation are vital for e-business development and is in consonance with previous research [22], [42], [56].

The third hypothesis, which states that technology in a nation is positively associated with e-business development, received strong support (path $=0.463, \mathrm{t}=3.90, \mathrm{p}<0.001$ ). Hypothesis 4 , indicating a positive relation between the government and e-business development in a nation, received strong support ( $p a t h=0.185, \mathrm{t}=2.77, \mathrm{p}<0.01$ ). These results indicate that both technology and government play an important role in e-business development of a nation. This result is consistent with previous research in e-business [42], [59] and other areas such as internet adoption [39], [48]. The model explains a significant amount of variance (82.4\%) in the e-business development. Table 3 summarizes the analysis results of the study. All dimensional constructs of the model are significant at $p<0.05$ level. The table also gives the Cronbach's Alpha for all constructs.

Table 3: Summary of analysis results

\begin{tabular}{|l|l|l|l|l|l|l|}
\hline $\mathbf{N}=61$ & $\begin{array}{l}\text { Standardized } \\
\text { Path Coefficient }\end{array}$ & Mean & $\begin{array}{l}\text { Standard } \\
\text { Deviation }\end{array}$ & t-stat & $\begin{array}{l}\text { Cronbach's } \\
\text { Alpha }\end{array}$ & $\mathbf{R}^{\mathbf{2}}$ \\
\hline Country Characteristics & 0.159 & 0.161 & 0.902 & 1.92 & 0.739 & \\
\hline Business & 0.160 & 0.169 & 0.072 & 1.93 & 0.915 & \\
\hline Technology & 0.463 & 0.455 & 0.124 & 3.90 & 0.929 & \\
\hline Government & 0.185 & 0.183 & 0.068 & 2.77 & 0.749 & \\
\hline E-business development & & & & & 0.777 & 0.825 \\
\hline
\end{tabular}




\section{Discussion and Implications}

Understanding facilitators for e-business development is vital for effective implementation and usage of e-business by a nation [17], [49]. E-business development in this study represents the maturity of nations to conduct their business transactions online. Facilitators for this aspect of e-business have not yet been studied in detail in past literature. Before we discuss the contributions of the study and its implementations, we want to discuss the limitations of this study first. For a cross-country study like this, collection of primary data would consume large amount of resources. Hence, due to the constraint of resources available for this research, we empirically test the proposed research model using the available data set with 61 countries from various secondary sources. In addition, we excluded some of the major countries such as Korea, Hong-Kong etc. after analyzing common data points due to insufficient data. Thus, the foremost limitation of the study is that since the study used secondary data from different sources, only a limited number of available countries are used.

Nevertheless, we expect that this study contributes greatly in this field of research. Most studies on e-business are either conceptual or case studies. There are relatively few studies that analyze empirically e-business development at a cross-country level [42], [59]. Also, to our best knowledge, there is no other study that examines e-business development alone from the cross-country scenario. The empirical analysis of the study, which uses secondary data to analyze e-business development, fills these gaps in e-business literature, making an important contribution for ebusiness research. We used TOE framework in this study for analyzing e-business development at the national level. There are only a few studies using TOE framework in cross-country perspective to analyze e-business development [42], [59]. TOE is applied and tested in a cross-country scenario in this study; TOE has served as a useful theoretical framework in the information systems domain for understanding adoption and performance of technological innovations. This research is one of pioneer studies that uses TOE framework for analysis of e-business development at a cross-country level.

The study results suggest that country characteristics are an important part for the development of e-business in a nation. Human capital is an important facilitator for e-business development. As discussed earlier, citizen's knowledge is a vital resource for e-business development of a country. Policy makers and country administrators should take steps towards increasing the literacy rate by setting up technological institutions and research \& development centers. As suggested by this study and earlier studies, corruption of a nation influences e-business development [5]. In certain developing countries, firms often face difficulty from government officials in the form of corruption in their administrative work. There are many studies that suggest the anti-corruption practices for nations [29], [45]. Country administrators should adhere to anti-corruption by revising their administration in favor of the firms. Measures should be taken deep from root-levels of the country to eradicate corruption. These results have an important implication for policy makers and country administrators to set up enhanced guidelines to manage the discussed two indicators. The result for this dimension is in consonance with few other studies [5], [21]-[22].

The results also highlight that both business environment and business competitiveness in a nation are positively associated with e-business development. Every country needs to have a prerequisite of business process development to increase e-business for the nation. A better environment for establishing businesses in a nation would enhance the use and development of e-business in the country. Although the country administrators and policy makers cannot directly influence the business activities, they should always support businesses to stay ahead in this global competitive world. Country administrators and policy makers need to create an environment where businesses can operate with minimum risk. Firms and Nations need to maintain competitiveness between them to increase e-business development. The result obtained through this dimension is an important contribution to the business literature, as it considers the impact of business processes at the national level. This result also has some implications to policy makers and practitioners for establishing new e-business guidelines by promoting their nations businesses.

We suggest that technology dimension is an important prerequisite for the development of e-business of a nation. We also suggest some indicators of technology that policy makers need to focus on for developing e-business of their nation. As suggested by earlier studies and this study, ICT Infrastructure is always an important factor for the development of e-business. Providing sufficient ICT infrastructure to the firms enhances e-business development. Especially in underdeveloped countries, country administrators should strive to establish strong infrastructure. Special plans and subsidies on the infrastructure could be a boom to the firms. Better telecommunication lines, personal computers, and network equipment should be supplied by the government at a flexible cost. They also need to setup new research \& development centers to encourage innovations. They need to provide funds towards research \& development centers to substantiate the innovations. Firms also should be ready enough to adopt these innovations and other technologies for a better e-business development in their nations. The increase in human capital enriches the technological readiness of a nation. Country administrators should concentrate on improving the technical infrastructure along with IT human resources. Although, outsourcing has not been supported by many countries, we suggest that IT human resources could be increased with outsourcing. Nations also need to build partnerships to share and support the technical infrastructure. These results are also in consonance with previous literature [21]-[22], [42]-[43], [59]. This result also greatly contributes to the literature of IT and e-business. 
According to previous research, e-government development in a country positively influences e-business development [42]. This is in consonance with our result. According to the results of the study, e-government development and e-participation of government dimension impact on the e-business development of a country. This highlights the importance of e-government for e-business development along with other indicators. In other words, the government plays an important role in e-business development. E-government projects for citizens and public domain, for example, enhance business to adopt e-business at a higher level. Government usage of ICT also greatly influences e-business development within a nation. Hence, a change in a government view for e-government projects would greatly influence e-business development. This has some vital implications for government administrators and policy makers. First, government administrators should encourage e-government projects through online websites and portals. This encourages the citizens and firms of a nation to actively get involved in the ICT technologies, there by aspiring better e-business development [44]. Second, country administrators need to get involved themselves with encouraging citizens to participate in the e-government process there by increasing the eparticipation of a nation. Third, the policies of the government should also be revised to furnish firms with a better opportunity to adopt e-business. Discounts, subsidies, special plans and better infrastructure need to be accommodated by the government in order to nourish the growth of firms. The aggregate growth of firms will increase the productivity of a nation as a whole. Hence, the government administrators can take these implications as guidelines to the development of e-business. Also, for the literature of e-government development, this study is also an additional asset.

For researchers, this model can help to develop more studies at the global level. There is a dearth for these kinds of studies, and any contribution to this key global study will be a good resource for literature. Researchers can take our model and further enhance it by adding more dimensions and variables. We expect that further study with a larger number of countries can contribute a lot to the literature. Also, researchers can perform the same kind of study without using secondary data. Although it is hard to obtain primary data directly from countries, any research that could obtain that kind of data can contribute greatly to the information systems literature.

\section{Conclusion}

In this study, we propose a Country-Business-Technological-Government (CBTG) based e-business framework for nations. The research model includes four dimensions for development of e-business in a nation. Together we analyzed the proposed model empirically with a set of data from 61 countries. The results of the study support for all the dimensions with the technology and government dimensions being strongly significant. Country administrators and policy makers can use the proposed model as a guide for e-business development for the country. Further research can attempt to understand e-business more at a global level and test the model with more countries. Another stream of research can explore the development of e-business by identifying more intermediate variables and adding more dimensions.

\section{Websites List}

Site 1: EuroStats www.epp.eurostat.ec.europa.eu/portal/page/portal/eurostat/home/

Site 2: Office for National Statistics (ONS) www.statistics.gov.uk/default.asp

Site 3: Transparency International Global http://www.transparency.org/

\section{References}

[1] N. Al-Qirim, The adoption and diffusion of e-commerce in developing countries: The case of NGO in Jordan, Information Technology for Development, vol. 13, no. 2, pp. 107-131, 2007.

[2] R. Amit and C. Zott, Value creation in e-business, Strategic Management Journal, vol. 22, no. 6-7, pp. 493-520, 2001.

[3] D. Barclay, C. Higgins, and R.Thompson, The partial least square (PLS) approach to casual modeling: Personal computer adoption and use as an illustration, Technology Studies Special Issue on Research Methodology, vol. 2, no. 2, pp. 285-309, 1995.

[4] S. Becker, E-government usability for older adults, Communications of ACM, vol. 48, no. 2, pp. 102-104, 2005.

[5] P. Berthon, L. Pitt, JP. Berthon, C. Campbell, and D. Thwaites, E-relationships for e-readiness: Culture and corruption in international e-B2B, Industrial Marketing Management, vol. 37, no. 1, pp. 83-91, 2007.

[6] I. Bogaert, R. Martens, and A. Van Cauwenbergh, Strategy as a Situational Puzzle: The Fit of Components, in Competence-Based Competition (G. Hamel and A. Heene, Eds.). Chichester, UK: John Wiley,1994, pp. 57-94.

[7] W. Chin, The partial least squares approach to structural equation modeling, Modern Methods for Business Research, vol. 295, no. 2, pp. 295-336, 1998. 
[8] N. Choucri, V. Maugis, S. E. Madnick, M. D. Siegel, S. E. Gillett, F. Haghseta, H. Zhu, and M. L. Best, Global ereadiness - for what? Readiness for e-banking, Information Technology for Development, vol. 11, no. 4, pp. 313-342, 2005.

[9] E. Cloete and M. Doens, B2B e-marketplace adoption in South African agriculture, Information Technology for Development, vol. 14, no. 3, pp. 184-196, 2008.

[10] A. Colecchia, Defining and measuring electronic commerce: Towards the development of an OECD methodology, in Proceedings of the International Statistical Institute Cutting Edge Conference on the Measurement of E-Commerce, Singapore, December, 1999.

[11] W. M. Cohen, R. R. Nelson, and J. P. Walsh, Links and impacts: The influence of public research on industrial R\&D, Management Science, vol. 48, no. 1, pp. 1-23, 2002.

[12] Q. Dai and R. Kauffman, Business models for Internet-based B2B electronic markets, International Journal of Electronic Commerce, vol. 6, no. 4, pp. 41-72, 2002.

[13] F. Damanpour and J. Damanpour, E-business e-commerce evolution: Perspective and strategy, Managerial Finance, vol. 27, no. 7, pp. 16-33, 2001.

[14] W. Darley, Public policy challenges and implications of the Internet and the emerging e-commerce for subSaharan Africa: A business perspective, Information Technology for Development, vol. 10, no. 1, pp. 1-12, 2003.

[15] A. Drobik, E-business country opportunity index, Gartner Research, Stamford, Connecticut, 2000.

[16] S. Dutta and A. Jain, An Analysis of the Diffusion of Information and Communication Technologies of Nations, The Global Information Technology Report, 2005.

[17] ECD-UNCTAD, E-commerce and development report, UNCTAD, New York, 2004.

[18] EIU, E-readiness rankings 2009: The usage imperative, Economist Intelligence Unit, 2009.

[19] C. Galve-Górriz and A. Gargallo Castel, The relationship between human resources and information and communication technologies: Spanish firm-level evidence, Journal of Theoretical and Applied Electronic Commerce Research, vol. 5, no. 1, pp. 11-24, 2010.

[20] D. Gefen, D. Straub, and M. Boudreau, Structural equation modeling and regression: Guidelines for research practice, Communications of the Association for Information Systems, vol. 4, pp. 7, October 2000

[21] J. Gibbs, K. L. Kreamer, and J. Dedrick, Environment and policy factors shaping global e-commerce diffusion: A cross-country comparison, The Information Society, vol. 19, no. 1, pp. 5-18, 2003.

[22] D. D. Gregorio, S. K. Kassicieh, and R. De Gouvea Neto, Drivers of e-business activity in developed and emerging markets, IEEE Transactions on Engineering Management, vol. 52, no. 2, pp. 155-166, 2005.

[23] D. Heil and J. Prieger, The macroeconomic impacts of e-business on the economy, in Encyclopedia of EBusiness Development and Management in the Digital Economy, Western Illinois University, 2009, pp. 1-11.

[24] S. Ho, R. Kauffman, and T. Liang, A growth theory perspective on the international diffusion of e-commerce, in Proceedings of the $7^{\text {th }}$ International Conference on Electronic Commerce, Xi'an, China, 2005, pp. 57-65.

[25] D. Jutla, P. Bodorik, and J. Dhaliwal, Government support for the e-readiness of small and medium sized enterprises, in Proceedings at the $35^{\text {th }}$ Annual Hawaii International Conference on System Sciences, Hawaii, USA, 2002, pp. 1-11.

[26] R. Kalakota and A. Whinston, Frontiers of electronic commerce. CA: Addison Wesely, 1996.

[27] G. Kannabiran and P. Narayan, Deploying internet banking and e-commerce - case study of a private-sector bank in India, Information Technology for Development, vol. 11, no. 4, pp. 363-379, 2005.

[28] D. Kim, An OBTG (Organizational-Business-Technological-Governmental) e-business adoption model for small and medium sized enterprises, in Proceedings of $14^{\text {th }}$ Americas Conference on Information Systems, Toronto, Canada, 2008, pp. 243.

[29] R. E. Klitgaard, Controlling corruption. Berkley and Los Angles, California: University of California Press, 1991.

[30] R. Krovi, Surveying the e-landscape: New rules of survival, Information Systems Management, vol. 18, no. 4, pp. 769-791, 2001.

[31] H. Lee and S. Whang, E-business and supply chain integration, in The Practice of Supply Chain Management: Where Theory and Application Converge (T. P. Harrison, H. L. Lee, and J. J. Neale, Eds.). NY: Springer, pp. 123-138, 2004.

[32] S. W. Lee and D. J. Kim, Driving factors and barriers of information and communication technology for ebusiness in SMEs: A case study in Korea, IADIS International Journal of WWW/Internet, vol. 2, no. 2, pp. 16-28, 2004.

[33] S. Moodley, Whither business-to-business electronic commerce in developing economies? The case of the South African manufacturing sector, Information Technology for Development, vol. 10, no. 1, pp. 25-40, 2003.

[34] A. Papazafeiropoulou and A. Pouloudi, The Government's role in improvinig electronic commerce adoption, in Proceedings of the $8^{\text {th }}$ European Conference on Information Systems, Vienna, Austria, 2000, pp. 709-716.

[35] M. Pankowska, National frameworks' survey on standardization of e-government documents and processes for interoperability, Journal of Theoretical and Applied Electronic Commerce Research, vol. 3, no. 3, pp. 64-82, 2008.

[36] D. Phan, E-business development for competitive advantages: A case study, Information \& Management, vol. 40, no. 6, pp. 581-590, 2002.

[37] M. Porter, Building the microeconomic foundations of prosperity: Findings from the business competitiveness index, World Competitiveness Report, 2004-2005.

[38] F. Purcell and J. Toland, Electronic commerce for the South Pacific: A review of e-readiness, Electronic Commerce Research, vol. 4, no. 3, pp. 241-262, 2004. 
[39] I. Rodríguez-Ardura, A. Meseguer-Artola, and J. Villaseca-Requena, Factors influencing the evolution of electronic commerce: An empirical analysis in a developed market economy, Journal of Theoretical and Applied Electronic Commerce Research, vol. 3, no. 2, pp. 18-29, 2008.

[40] S. Simon, Critical success factors for electronic services: Challenges for developing countries, Journal of Global Information Technology Management, vol. 7, no. 2TY-JOUR, pp. 31, 2004.

[41] M. Spremic and V. Hlupic, Development of e-commerce in Croatia: A survey, Information Technology for Development, vol. 13, no. 4, pp. 391-409, 2007.

[42] S. Srivastava and T. Teo, Determinants and impact of e-government and e-business development: A global perspective, in Proceedings presented at the International Conference on Information Systems, Wisconsin, 2006, pp. 365-378.

[43] S. Srivastava and T. Teo, What facilitates e-government development? A cross-country analysis, Electronic Government: An International Journal, vol. 4, no. 4, pp. 365-378, 2007.

[44] S. Srivastava and T. Teo, E-government, e-business, and national economic performance, Communications of the Association for Information Systems, vol. 26, no. 1, pp. 14, 2010.

[45] R. Stapenhurst and S. Kpundeh, Curbing Corruption: Toward a Model for Building National Integrity. Washington: World Bank Publications, 1999.

[46] M. Subramani, How do suppliers benefit from information technology use in supply chain relationships?, MIS Quarterly, vol. 28, no. 1, pp. 45-73, 2004.

[47] R. Tehan, E-commerce Statistics: Explanation and Sources, The Library of Congress, CRS Report for Congress, 2003.

[48] T. Teo, M. Tan, and W. K. Buk, A contingency model of Internet adoption in Singapore, International Journal of Electronic Commerce, vol. 2, no. 2, pp. 95-118, 1997.

[49] UNReport, UN E-government Survey 2008: From E-Government to Connected Government, 2008.

[50] WEF, The Global Competitiveness Report 2008-2009, World Economic Forum, Geneva2008.

[51] WEF, Global Information Technology Report, World Economic Forum, 2009.

[52] Z. D. Wigder, Asia pacific online retail forecast, 2010 to 2015, Forrester Research, Cambridge, MA, 2010.

[53] $\mathrm{H}$. Wold, Introduction to the second generation of multivariate analysis, in Theoretical empiricism: A general rationale for scientific model-building, H. Wold, Ed. New York: Paragon House, 1989, pp 12-40.

[54] P. Wong, Global and national factors affecting e-commerce diffusion in Singapore, The Information Society, vol. 19, no. 1, pp. 19-32, 2003.

[55] F. Wu, V. Mahajan, and S. Balasubramanian, An analysis of e-business adoption and its impact on business performance, Journal of the Academy of Marketing Science, vol. 31, no. 4, pp. 425-447, 2003.

[56] K. Zhu and K. Kraemer, Post- adoption variations in usage and value of e-business by organizations: Crosscountry evidence from the retail industry, Information Systems Research, vol. 16, no. 1, pp. 61-84, 2005.

[57] K. Zhu, K. L. Kreamer, and J. Dedrick, Information technology payoff in e-business environments: An international perspective on value creation of e-business in the financial services industry, Journal of Management Information Systems, vol. 21, no. 1, pp. 17-54, 2004.

[58] K. Zhu, K. L. Kreamer, and S. Xu, Electronic business adoption by European firms: A cross-country assessment of the facilitators and inhibitors, European Journal of Information Systems - Managing e-business, vol. 12, no. 4, pp. 251-268, 2003.

[59] K. Zhu, K. L. Kreamer, and X. Su, A cross-country study of electronic business adoption using the technologyorganization-environment framework, in Proceedings of the International Conference On Information Systems, Barcelona, 2002, pp 337-348. 